\title{
Reactions of Iminophosphanes with Chlorotris(triphenylphosphine)rhodium(l): Generation and NMR Identification of the First Iminophosphanerhodium(I) and Iminophosphanerhodium(III) Complexes
}

\author{
Vadim D. Romanenko, " Alexander V. Ruban," Alexander B. Roshenko," Mark I. Povolotskii," Tatjana V. Sarina," \\ Dietrich Gudat ${ }^{b}$ and Edgar Niecke*b \\ - Institute of Organic Chemistry, Academy of Sciences of the Ukraine, 253660 Kiev 94, Ukraine. \\ - Anorganisch-Chemisches Institut der Universität, Gerhard-Domagk-Str. 1, D-5300 Bonn-1, Germany. Fax: + 49228735327
}

Iminophosphanes [RO-P $\Rightarrow \mathrm{NAr}$ ] $\left(\mathrm{R}=\mathrm{Me}, 2-\mathrm{MeC}_{6} \mathrm{H}_{4} ; \mathrm{Ar}=2,4,6-\mathrm{Bu}_{3} \mathrm{C}_{6} \mathrm{H}_{2}\right)$ 1a,b react with $\mathrm{RhClL}_{3}\left(\mathrm{~L}=\mathrm{Ph}_{3} \mathrm{P}\right)$ via ligand exchange to give $\kappa P$-iminophosphane complexes of rhodium(1) [RhCl(MeOP $\left.\Rightarrow \mathrm{NAr})_{2} \mathrm{~L}\right] 2$ and $\left[\mathrm{PhCl}\left(2-\mathrm{MeC}_{6} \mathrm{H}_{4} \mathrm{OP}=\mathrm{NAr}\right) \mathrm{L}_{2}\right] 3$. Under analogous conditions, $P$-halogenoiminophosphanes $[X-P=N A r](X=C l, B r, I) 3 a-c$ undergo a facile oxidative addition of the $\mathrm{P}-\mathrm{X}$ bond, forming five-coordinate iminophosphanerhodium(III) complexes of composition $\left[\mathrm{L}_{2} \mathrm{Cl}(\mathrm{X}) \mathrm{Rh}(\sigma-\mathrm{P}=\mathrm{BAr})\right] \mathbf{5}$.

Transition metal iminophosphane complexes have attracted considerable interest because of their novel bonding features. Since 1977 a large number of such species have been synthesized and structurally characterized.' In these studies, attention has focused on the $P$-aminoiminophosphanes $\left[\mathrm{R}_{2} \mathrm{~N}-\mathrm{P}=\mathrm{NR}\right]{ }^{2}$ Compared with the latter, very little is known about the ligating properties of other types of $P$-functionalized iminophosphanes, especially those containing a reactive $\mathrm{X}-\mathrm{P}$ single bond. ${ }^{3}$ We report herein our initial observations which include $(a)$ the generation and NMR characterization of novel $P$-alkoxy- (or aryloxy-) (2,4,6-tri-tert-butylimino)phosphane-k $P$ rhodium(I) complexes, and $(b)$ the discovery of a facile oxidative addition of the halogeno(2,4,6-tri-tert-butylimino)phosphanes to rhodium(I) resulting in the formation of five-coordinate iminophosphane-k $P$ rhodium(III) complexes.

Whereas reaction of $\left[\mathrm{RhClL}_{3}\right]$ with an equimolar amount of $1 \mathrm{a}^{4}$ in toluene-dichloromethane solution (1:2) at room temperature produced only broad signals in the ${ }^{31} \mathrm{P}\left\{{ }^{\prime} \mathrm{H}\right\}$ NMR spectrum, treatment with an excess of $1 \mathrm{a}$ ( 3 equiv.) produced an NMR spectrum showing an $A B M X$ pattern $(X=R h)$ attributable to 2 (Table 1 ). The AB resonances, which are assigned to two iminophosphane ligands, display rather small coordination shifts with respect to free $\mathbf{1 b}$ which is generally associated with a $\kappa P$-coordination mode $\left(c f^{5}\right)$. The symmetry of the spectrum and the trans-coupling between $\mathrm{P}^{\mathrm{A}}$ and $\mathrm{P}^{\mathrm{M}}(454 \mathrm{~Hz})$ prove the cis-arrangement of the coordinated iminophosphanes.

The reaction of $\left[\mathrm{RhClL}_{3}\right]$ with an excess of $\mathbf{1 b}^{5}$ at room temperature in a toluene-dichloromethane mixture $(2 \mathrm{~h}$ reaction time) gave the monosubstituted iminophosphanerhodium(I) complex 3 as a ca. 4:1 mixture of trans and cis isomers. The observed $\mathrm{AM}_{2} \mathrm{X}$ and $\mathrm{AMNX}(\mathrm{X}=\mathrm{Rh})$ spectra show chemical shifts and ' $J_{\text {RhP }}$ coupling constants for each type of ligand which are similar to 2 , also suggesting ${ }_{\kappa} P$-coordination of the iminophosphane. The ${ }^{1} J_{\mathrm{RhP}}$ values of $\mathbf{2}$ and $\mathbf{3}$ are typical for complexes of four-coordinate $\mathrm{Rh}(\mathrm{I})$. As compared with $\mathrm{Ph}_{3} \mathrm{P}$, the iminophosphane ligands show a greater magnitude of ' $J_{\mathrm{RhP}}$ due to the formal $\mathrm{sp}^{2}$-hybridisation at phosphorus. This coupling is further increased if the iminophosphane is in a trans-position to the chloride, indicating a higher degree of $\pi$-backbonding from the ligand in this case.

Solutions of $\mathbf{2}$ and $\mathbf{3}$ were stable for many days at room temperature with excess free iminophosphane ligand present.
Table $1{ }^{31} \mathrm{P}\left\{{ }^{\prime} \mathrm{H}\right\}$ and ${ }^{15} \mathrm{~N}$ NMR data for complexes 2,3 and $5 \mathrm{a}-\mathrm{e}$

\begin{tabular}{|c|c|c|c|c|c|c|}
\hline Complex & $\delta^{31} \mathrm{P}^{\alpha}$ & ${ }^{1} J_{\mathrm{RhP}}{ }^{b}$ & ${ }^{2} J_{\mathrm{PP}}{ }^{b}$ & $\delta^{15} \mathrm{~N}^{a, c}$ & $J_{\text {NP }}$ & $J_{\mathrm{NRh}^{b}}{ }^{b}$ \\
\hline \multirow[t]{3}{*}{2} & $137.9 \mathrm{P}^{\mathrm{A}}$ & 304 & 67 (AB) & & & \\
\hline & $120.7 \mathrm{P}^{\mathrm{B}}$ & 195 & 34 (AM) & & & \\
\hline & $24.6 \mathrm{P}^{\mathrm{M}}$ & 125 & 454 (BM) & & & \\
\hline \multirow[t]{2}{*}{ trans-3 } & $123.4 \mathrm{P}^{\mathrm{A}}$ & 334 & $55(\mathrm{AM})$ & & & \\
\hline & $31.4 \mathrm{P}^{\mathrm{M}}$ & 124 & & & & \\
\hline \multirow[t]{3}{*}{ cis-3 } & $117.6 \mathrm{P}^{\mathrm{A}}$ & 223 & $465(\mathrm{AM})$ & & & \\
\hline & $51.8 \mathrm{P}^{\mathrm{M}}$ & 190 & 55 (AN) & & & \\
\hline & $30.8 \mathrm{P}^{\mathrm{N}}$ & 121 & $36(\mathrm{NM})$ & & & \\
\hline \multirow[t]{2}{*}{$5 a$} & $323.9 \mathrm{P}^{\mathrm{A}}$ & 74 & 4 (AM) & -91 & 87.1 & ${ }^{\prime} J_{P N}$ \\
\hline & $24.8 \mathrm{P}^{\mathrm{M}}$ & 106 & & & 3.6 & \\
\hline \multirow{2}{*}{$5 b$} & $309.2 \mathrm{P}^{\mathrm{A}}$ & 80 & 7 (AM) & & & \\
\hline & $26.1 \mathrm{P}^{\mathrm{M}}$ & 101 & & & & \\
\hline \multirow[t]{2}{*}{$5 c$} & $272.4 \mathrm{P}^{\mathrm{A}}$ & 102 & 19 (AM) & & & \\
\hline & $25.5 \mathrm{P}^{\mathrm{M}}$ & 98 & & & & \\
\hline \multirow[t]{2}{*}{ 5d } & $288.3 \mathrm{P}^{\mathrm{A}}$ & 89 & 9 (AM) & -114 & 89.1 & ${ }^{\prime} J_{\mathrm{PN}}$ \\
\hline & $24.3 \mathrm{P}^{\mathrm{M}}$ & 101 & & & $\begin{array}{l}2.7 \\
2.0\end{array}$ & $\begin{array}{l}{ }^{2} J_{\mathrm{RhN}} \\
{ }^{3} J_{\mathrm{PNN}}\end{array}$ \\
\hline \multirow[t]{2}{*}{$5 e$} & $237.2 \mathrm{P}^{\mathrm{A}}$ & 115 & $22(\mathrm{AM})$ & $-147^{d}$ & 95.2 & $J_{\mathrm{PN}}$ \\
\hline & $22.3 \mathrm{P}^{\mathrm{M}}$ & 99 & & & & \\
\hline
\end{tabular}

"In ppm (121.5 MHz, $\mathrm{C}_{6} \mathrm{D}_{5} \mathrm{CD}_{3}-\mathrm{CH}_{2} \mathrm{Cl}_{2}$, ext. $\left.\mathrm{H}_{3} \mathrm{PO}_{4}\right)$. "In $\mathrm{Hz}$. $\cdot 30.4 \mathrm{MHz}, \mathrm{C}_{6} \mathrm{D}_{5} \mathrm{CD}_{3}-\mathrm{CH}_{2} \mathrm{Cl}_{2}$, ext. $\mathrm{CH}_{3} \mathrm{NO}_{2} \cdot{ }^{d}$ Broad signals.

Attempts to remove the solvent and excess $\mathrm{PPh}_{3}$ and 1a,b, however, resulted in decomposition and formation of $\left[\mathrm{RhL}_{2} \mathrm{Cl}\right]_{2}$. In contrast to $\mathbf{1 a}, \mathbf{b}$ the sterically crowded $\mathbf{1 c}$ is unreactive towards $\left[\mathrm{RhClL}_{3}\right]$ (five-fold excess iminophosphane, 2 weeks at $20^{\circ} \mathrm{C}$ ); obviously in this case the bulky aryloxygroup on phosphorus prevents $\kappa P$-coordination.

A different type of interaction was observed during the reactions of $\left[\mathrm{RhClL}_{3}\right]$ with the halogenoiminophosphanes $4 .^{6}$ When $4 \mathrm{a}(0.5 \mathrm{mmol})$ in toluene $(1.5 \mathrm{ml})$ was allowed to react with an equimolar quantity of the rhodium complex in dichloromethane $(2 \mathrm{ml})$ at $-30^{\circ} \mathrm{C}$, a very rapid reaction occurred with liberation of one $\mathrm{PPh}_{3}$ ligand. The resulting new complex was isolated in $69 \%$ yield as a brick-red, air- and moisturesensitive microcrystalline solid after evaporation of the solvent and crystallization from a cyclohexane- $\mathrm{CH}_{2} \mathrm{Cl}_{2}$ (1:1) solution at $-10^{\circ} \mathrm{C}$. Elucidation of the constitution of the product as metal-substituted iminophosphane $5 \mathrm{a}$ was possible on the basis 


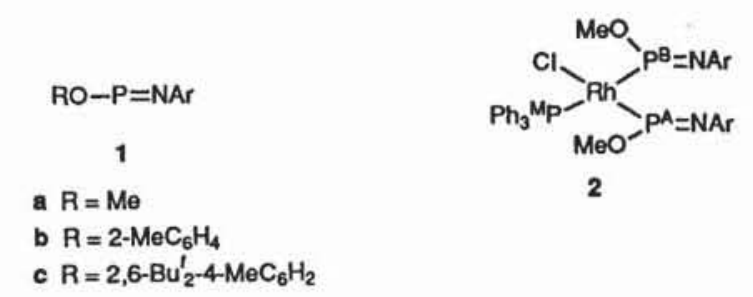

$\mathrm{Ar}=2,4,6-\mathrm{Bu}_{3}^{t} \mathrm{C}_{6} \mathrm{H}_{2}$

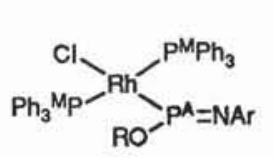

trans -3

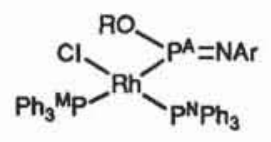

cis -3
$\mathrm{R}=2-\mathrm{MeC}_{6} \mathrm{H}_{4}$

Scheme 1

of its ${ }^{31} \mathrm{P}\left\{{ }^{\prime} \mathrm{H}\right\}$ NMR spectrum showing an $\mathrm{A}_{2} \mathrm{MX}$ spin system $\left(A, M={ }^{31} \mathrm{P} ; \mathrm{X}={ }^{103} \mathrm{Rh}\right)$. The $\mathrm{P}^{\wedge}$ resonance exhibits a downfield shift of more than $200 \mathrm{ppm}$ relative to uncoordinated $\mathbf{1 b}$ as well as significantly reduced values of both ${ }^{1} J_{\mathrm{RhP}}$ and ${ }^{2} J_{\mathrm{pP}}$ which are diagnostic for a transition metal-substituted phosphorus $\mathrm{p} \pi$ system. ${ }^{7} \dagger$ Further, the ${ }^{1} J_{\mathrm{RhPA}}$ coupling constant of the $\mathrm{Ph}_{3} \mathrm{P}$ ligands is much smaller than in $\mathbf{2 , 3}$, but is quite comparable with those in the five-coordinate acylrhodium(III) complexes $\left[\text { trans- }\left(\mathrm{Ph}_{3} \mathrm{P}\right)_{2} \mathrm{Cl}_{2} \mathrm{Rh}(\sigma-\mathrm{COR})\right]^{11}$ which form in the reactions of $\left[\mathrm{RhClL}_{3}\right]$ with acyl chlorides. $¥$ The structural formulation of $5 \mathrm{a}$ is also supported by the similarity of the ${ }^{31} \mathrm{P}$ NMR parameters with those of $\left(\mathrm{R}_{3} \mathrm{P}_{2}\right) \mathrm{XM}\left[\sigma-\mathrm{P}=\mathrm{C}\left(\mathrm{SiMe}_{3}\right)_{2}\right](\mathrm{M}=\mathrm{Ni}, \mathrm{Pt} ; \mathrm{X}=\mathrm{Br}$, I), which were obtained in an analogous reaction by oxidative addition of complexes of $\mathrm{Ni}^{\circ}$ and $\mathrm{Pt}^{\circ}$ with halogenophosphaalkenes. ${ }^{10}$ It is essential that like the latter, $5 a$ is quite inert towards $\left[\mathrm{RhCl}(\mathrm{CO}) \mathrm{L}_{2}\right]$ which is much less reactive in oxidation addition reactions than $\left(\mathrm{RhClL}_{3}\right] \cdot{ }^{14}$ In a similar way as $4 \mathrm{a}$, the bromo- and iodo-iminophosphanes $\mathbf{4 b}, \mathbf{c}$ easily reacted with $\mathrm{RhClL}_{3}$ to give complexes $\mathbf{5 b}$,c together with the halogen exchange products $\mathbf{5 a}$ and $\mathbf{5 d}, \mathbf{e}$, respectively. After addition of excess $\mathrm{Me}_{3} \mathrm{SiBr}$ or $\mathrm{Me}_{3} \mathrm{Sil}$ to the reaction mixtures, ${ }^{15}$ followed by concentration of the solutions and re-crystallization of the residue from cyclohexane-dichloromethane $(1: 1)$, the complexes $5 d, e$ were isolated in pure form. $\S$

In conclusion, the synthesis of the iminophosphanerhodium(III) complexes is the first example of direct oxidative addition of $P$-halogenoiminophosphanes to transition metal derivatives. In a broader context, the results presented here suggest that reactions of $P$-functionalized iminophosphanes with low-valent group 6 and 8-10 metal complexes possess a

+ Formally, the observed strong deshielding of $\mathrm{P}^{\wedge}$ and the small $J_{\mathrm{RhPA}}$, $J_{\mathrm{p} \wedge \mathrm{p} M}$ values may be explained by $\kappa N$-ligation of $4 .^{8}$ However, taking into account the pattern of reactivity of halogenoiminophosphanes ${ }^{6.9}$ and the very small magnitude of the $J_{R h}{ }^{1} \mathrm{~N}$ coupling $(<4 \mathrm{~Hz})$, this assumption should be dropped.

$\ddagger$ It seems highly likely that the complexes $\mathbf{5}$ are of square pyramidal structure similar to the above acylrhodium(iii) compounds where the $\sigma$-bonded carbon donor is in an apical position. ${ }^{12}$ However, there may be considerable distortion from square pyramidal geometry, and a five-coordinate complex having a trigonal bipyramidal structure cannot be excluded. The assumption of a trans-diequatorial configuration of $\mathrm{Ph}_{3} \mathrm{P}$ is based on data ${ }^{11.13}$ according to which ' $J_{\mathrm{RhP}}$ for a phosphorus trans to a halogen is larger than ' $J_{\mathrm{RhP}}$ for two phosphorus atoms trans to each other. A phosphorus trans to a chloride also resonates at lower field than do mutually trans phosphines, e.g. $\left[\left(\mathrm{Ph}_{3} \mathrm{P}\right)_{2} \mathrm{Cl}_{2} \mathrm{Rh}(\mathrm{COMe})\right]: \delta_{\mathrm{p}} 29.8,{ }^{1} J_{\mathrm{RhP}} 145 \mathrm{~Hz}$ (cis): $\delta_{\mathrm{p}} 23.6,{ }^{\prime} J_{\mathrm{RhP}}$ $108 \mathrm{~Hz}$ (trans). Our attempts to grow crystals suitable for X-ray diffraction failed.

§ The compounds 5a,d,e gave 'H NMR spectra and elemental analyses consistent with the assigned structures.

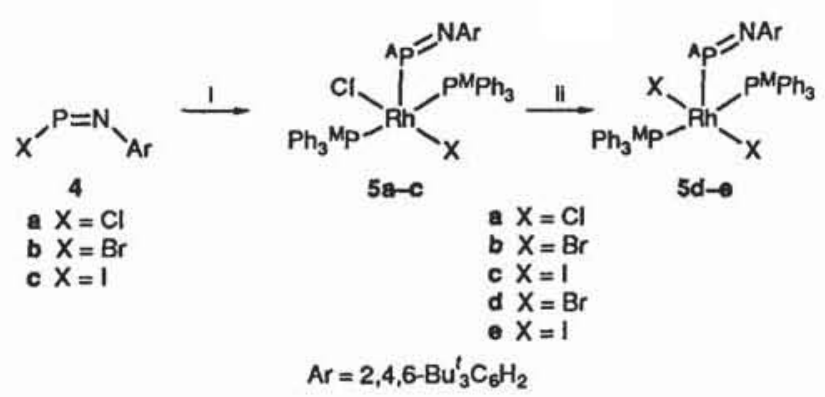

Scheme 2 Reagents and conditions: i, $\mathrm{RhCl}\left(\mathrm{PPh}_{3}\right)_{3}$ (1 equiv.), toluene$\mathrm{CH}_{2} \mathrm{Cl}_{2}(1: 2),-30^{\circ} \mathrm{C}, 0.5 \mathrm{~h}$; ii, $\mathrm{Me}_{3} \mathrm{SiBr}$ or $\mathrm{Me}_{3} \mathrm{SiI}$ (excess), benzene, room temp., $3 \mathrm{~h}$

considerable potential in view of the synthesis of new types of metalloiminophosphanes.

We thank the Alexander von Humboldt-Stiftung for the grant of a post doctoral fellowship (to A.V.R.) and the Ukrainian Academy of Sciences for financial support.

\section{References}

1 E. Niecke and D. Gudat, Iminophosphines in Multiple Bond and Low Coordination in Phosphorus Chemistry, eds. M. Regitz and O. J. Scherer, Thieme Verlag Stuttgart, 1990, p. 293.

2 O. J. Scherer, Angew. Chem ., Int. Ed. Engl., 1985, 24, 924; L. N. Markovskii, V. D. Romanenko and A. V. Ruban, Chemistry of Acyclic Compounds of Two-coordinated Phoshorus, Naukova Dumka, Kiev, 1988, p. 123.

3 J. Hein, E. Niecke, M. F. Meidine, B. F. Trigo Passos and J. F. Nixon, J. Chem. Soc., Chem. Commun., 1991, 41.

4 V. D. Romanenko, M. Sanchez, G. V. Reitel, A. N. Chernega, O. V. Kirichenko, A. V. Ruban, R. Wolf and M. R. Mazieres, Heterotaom Chem., accepted for publication.

5 P. B. Hitchcock, M. F. Meidine, J. F. Nixon, H. Wang, D. Gudat and E. Niecke, J. Organomet. Chem., 1989, 368, C29.

6 E. Niecke, M. Nieger and F. Reichert, Angew. Chem., Int. Ed. Engl., 1988, 27, 1715; V. D. Romanenko, A. V. Ruban, G. V. Reitel, M. I. Povolotskii, A. N. Chernega and L. N. Markovskii, Zh. Obshch. Khim., 1989, 592780 [J. Gen. Chem. USSR (Engl. Trans.), 1989,59, 2483].

7 D. Gudat, E. Niecke, B. Krebs and M. Dartmann, Chimia, 1985, 39, 277; P. Jutzi and U. Meyer, Chem. Ber., 1988, 122, 559; A. H. Cowley, N. C. Norman and S. Quashie, J. Am. Chem. Soc., 1984, 106, 5007; D. Gudat and E. Niecke, J. Chem. Soc., Chem. Commun., 1987, 11; E. Niecke, J. Hein and M. Nieger, Organometallics, 1989, 8, 2290.

8 L. N. Markovskii, V. D. Romanenko, A. V. Ruban, A. B. Drapailo, G. V. Reitel and T. V. Sarina, Phosphorus, Sulfur and Silicon, 1990, 49/50, 329.

9 W. W. Schoeller, T. Busch and E. Niecke, Chem. Ber., 1990, 123, 1653.

10 D. Gudat, M. F. Meidine, J. F. Nixon and E. Niecke, J. Chem. Soc., Chem. Commun., 1989, 11.

11 D. L. Egglestone, M. C. Baird, C. J. L. Lock and G. Turner, J. Chem. Soc. Dalton Trans., 1977, 1576.

12 YJ. Y. Shie, Y. C. Lin and Y. Wang, J. Organomet. Chem., 1989, $371,383$.

13 P. S. Pregosin and W. R. Kunz, ${ }^{31} P$ and ${ }^{13} C$ NMR of Transition Metal Phosphine Complexes, in NMR - Basic Principles and Progress, vol. 16, Springer Verlag Berlin, 1979, p. 38, and references cited therein.

14 J. P. Collman, L. S. Hegudus, J. R. Norton and R. G. Finke, Principles and Applications of Organotransition Metal Chemistry, Univ. Science Books, 1987, p. 279.

15 H. Yamashita, T.-A. Kabayashi, T. Hayashi and M. Tanaka, Chem. Lett., 1989, 471.

Received: Cambridge, 4th August 1992

Moscow, 17th September 1992; Com. 2/04605I 